\title{
The bayesian thinking, a pervasive computational thinking
}

\section{El pensamiento bayesiano, un pensamiento computacional omnipresente}

\author{
Miguel Zapata-Ros \\ Universidad de Murcia. Murcia. España \\ mzapata@um.es \\ Yamil Buenaño Palacios \\ Universidad de San Buenaventura. Bogotá. Colombia \\ ybuenano@usbbog.edu.co
}

\section{Summary}

In its simplest sense, computational thinking is considered as a series of specific skills that help programmers to do their homework, but that are also useful to people in their professional life and in their personal life as a way to organize the resolution on their problems, and of representing the reality that surrounds them.

In a more elaborate scheme, this complex of skills constitutes a new literacy --- or the most substantial part of it --- and an inculturation to deal with a new culture, the digital culture in the knowledge society.

We have seen how Bayesian probability is used in epidemiology models to determine models for the evolution of data on contagion and deaths in COVID and in natural language processing.

We could also see it in a multitude of cases in the most varied scientific and process analysis fields. In this way, with the automation of Bayesian methods and the use of probabilistic graphical models, it is possible to identify patterns and anomalies in voluminous data sets in fields as diverse as linguistic corpus, astronomical maps, add functionalities to the practice of the magnetic resonance imaging, or to card, online or smartphone purchasing habits.

In this new way of proceeding, big data analysis and Bayesian theory are associated.

If we consider that Bayesian thinking, this way of proceeding, as one more and more relevant element of computational thinking, then to what has been said on previous occasions we must now add the idea of generalized computational thinking, which goes beyond education.

It is no longer about aspects purely associated with ordinary professional or vital practice to deal with life and the world of work, as has been what we have called computational thinking until now, but as a preparation for basic research and research methodology in almost all disciplines. Because, thus defined, computational thinking is influencing research in almost all areas, both in the sciences and in the humanities.

An instruction focused on this component of computational thinking, Bayesian thinking, of including it at an early stage, in Secondary (K-12), including the inverse probability formula, would allow, based on Merrill's First principles of learning, and in particular in the activation principle, activate these learning as very valuable and very complex components in a later stage of professional or research activity, or in the training passed, undergraduate and postgraduate degrees, of these professions or that train for these activities and professions.

\section{Keywords}

Computational thinking, Bayesian thinking, pervasive computational thinking, science after the pandemic, education after the pandemic, Technology Education. 


\section{Resumen. -}

En su acepción más sencilla se considera el pensamiento computacional como una serie de habilidades específicas que sirven a los programadores para hacer su tarea, pero que también son útiles a la gente en su vida profesional y en su vida personal como una forma de organizar la resolución de sus problemas, y de representar la realidad que hay en torno a ellos.

En un esquema más elaborado este complejo de habilidades constituye una nueva alfabetización ---o la parte más sustancial de ella--- y una inculturación para manejarse en una nueva cultura, la cultura digital en la sociedad del conocimiento.

Hemos visto cómo se usa la probabilidad bayesiana, en modelos de epidemiología, para determinar modelos de evolución de datos sobre contagio y fallecimientos en el COVID y en el procesamiento del lenguaje natural.

Igualmente podríamos verlo en multitud de casos en los más variados campos científicos y de análisis de procesos. De esta forma, con la automatización de los métodos bayesianos y el uso de modelos gráficos probabilísticos es posible identificar patrones y anomalías en voluminosos conjuntos de datos en campos tan diversos como son los corpus lingüísticos, los mapas astronómicos, añadir funcionalidades a la práctica de la resonancia magnética, o a los hábitos de compra con tarjeta, online o smartphones.

En esta nueva forma de proceder, se asocian el análisis de grandes datos y la teoría bayesiana.

Si consideramos que el pensamiento bayesiano, esta forma de proceder, como un elemento más y relevante del pensamiento computacional, entonces a lo dicho en anteriores ocasiones hay que añadir ahora la idea de pensamiento computacional generalizado , que va más allá de la educación

Ya no se trata de aspectos puramente asociados a la práctica profesional o vital ordinaria para manejarse por la vida y el mundo del trabajo, como ha sido lo que hemos llamado pensamiento computacional hasta ahora, sino como una preparación para la investigación básica y para metodología investigadora en casi todas las disciplinas. Porque, así definido, el pensamiento computacional está influyendo en la investigación en casi todas las áreas, tanto en las ciencias como en las humanidades.

Una instrucción centrada en esta componente de pensamiento computacional, el pensamiento bayesiano, o que lo incluyese en una fase temprana, en Secundaria (K-12), incluyendo la fórmula de la probabilidad inversa, permitiría, basándonos en los First principles of learning de Merrill, y en particular en el principio de activación, activar estos aprendizajes como componentes muy valiosos y muy complejos en una etapa posterior de la actividad profesional o investigadora, o en la fase de formación, grados y postgrados, de estas profesiones o que capacitan para estas actividades y profesiones.

\section{Palabras clave. -}

Pensamiento computacional, pensamiento bayesiano, pensamiento computacional omnipresente, ciencia tras la pandemia, educación tras la pandemia, Educación Tecnológica.

In this article we want to justifiably and documentary highlight a trend that is taking place in science with repercussions on education, as always happens, and with demands for it. Until now, computational thinking had been conceived as something mainly linked to education and the learning needs that current society poses (Wing, 2006; 
Zapata Ros, 2015). Professional needs and social needs: coping in a new culture. It was conceived as a new literacy. Now, independently of education, but strongly linked to it, a new way of thinking has appeared that would not make sense without computers and networks, without the possibility of process and massive data circulation. Therefore, it is a form of computational thinking that is not deferred to be activated in the profession or in research, but rather arises in them. It is Bayesian thinking. These ideas are what we intend to develop in a work that has the nature of theoretical debate and analysis of the relationships between learning, teaching and technology and of analysis of policies and strategies at the institutional, regional, sectoral, national or international level, in line with RED themes. As a contribution that participates in the nature of a critical review of the literature and a theoretical essay.

\section{Approach}

On March 20, The Lancet publishes the article Estimates of the severity of coronavirus disease 2019: a model-based analysis (Verity, R. et al. 2020).

The idea it raises is simple and constitutes the most defined and pure scheme of a case of application of the Bayes' Theorem, with the help of data analytics: it focuses on Hubei (China), where the pandemic first arises and from there it is spread, it is known those infected by COVID 19 who died, how they are distributed by age and the time that elapses from the detection of the disease to death. In the rest of the countries, there were no patterns yet regarding this question, how the pandemic would affect the most serious cases of death, depending on these variables.

Under these conditions, it is easy by Bayes' Theorem (applied with data analytics to a very large number of cases), from the data obtained in Hubei to establish the probability that someone, who has contracted the disease, will take it in modality severe (with severe respiratory difficulties) and his possible death, as well as the number of days that he will be hospitalized and in the ICU. With this data it is easy to make forecasts to avoid the collapse of the system. Models were also given for other variables defined from the situations of the patients in relation to the frequency of travel or places of origin.

This is an example of how, with a simple mathematical result, complex models can be built to obtain probabilistically the behavior of groups, communities of individuals or data aggregates subject to a probability or a risk whose a priori distribution is unknown.

In the following figure (Fig. 1) you can see the pyramid with the spectrum of COVID 19 cases a posteriori, which is obtained in the known and studied cases and in the same way the pyramid can be built a priori from the data of the base with the application of Bayes' Theorem to both data sets, the a posteriori and the base of the pyramid a priori. 
Location

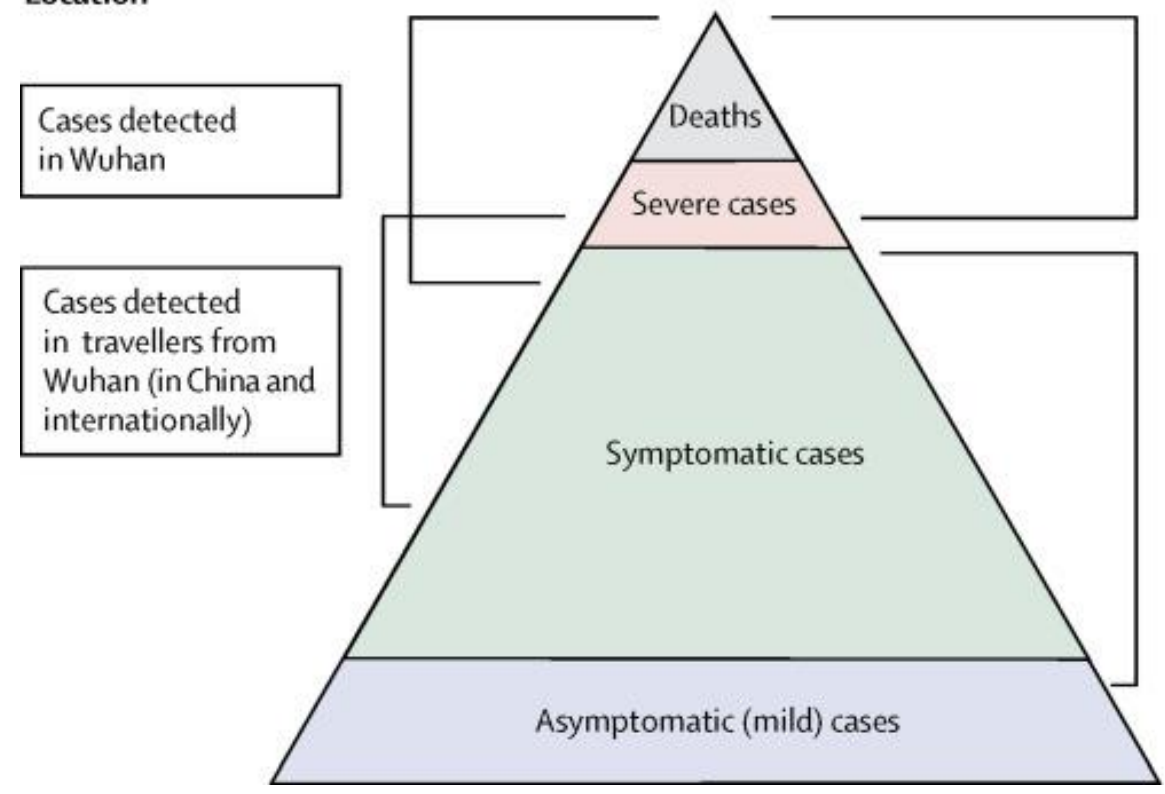

Surveillance

Cases detected internationally by hospital surveillance

Cases detected by contact tracing and influenza-like illness surveillance

Fig. 1 Pyramid with the spectrum of COVID 19 cases. Estimates of the severity of coronavirus disease 2019: a model-based analysis, of Robert Verity, $\mathrm{PhD} \dagger$ et al. (2020)

This, which happened in relation to Hubei and its precedent with respect to COVID and its behavior that thanks to Bayesian probability and data analytics, allowed to establish predictive patterns for other regions of the world, in which statistics were not known a priori behavior of the pandemic or were doubtful due to official data, it happens frequently in science, in the course of investigations with fuzzy data, as well as in professional practice when data subject to a dynamic similar to that described for Hubei and COVID.

Now let's look at another field: linguistics, natural language machine learning, and natural language processing (NLP). In it we find this book by Shay Cohen (2019) entitled Bayesian Analysis in Natural Language Processing, and reviewed by Brett Drury (2019 Aug):

It argues that probabilistic reasoning and analysis is a subfield of machine learning applied to natural language processing (NLP). And, in context, a field of Probability, Bayesian statistics, can offer unique techniques for NLP.

As in the rest of the Bayesian tradition, but now supported by the analysis of large data sets, the assignment of probability to an event is based on the probability of its inverse (a priori probability), through the result of known experiments (inverse probability, compound probability, and Bayes' Theorem). In contrast to the other great classical school, the assignment through frequency (deterministic or frequentist probability) (Drury, 2019 Aug): 
Cohen states that the goal of Bayesian Point Estimation as: "summarizing the posterior over the parameters into a fixed set of parameters", and he links this goal to a frequentist approach known as maximum likelihood estimation. Cohen states that Bayesian maximum a posterior estimation (MAP) is a suitable technique. The remainder of the section describes the mathematical principles of MAP as well its ability to adhere to the Minimum Message Length principle which is an encapsulation of Occam's Razor. The section also includes sub-sections on smoothing (default probabilities for words that are absent from the sample data) and regularization as well as the computation of MAP with latent variables.

In another work Barrow (2019 Apr), glossing Cohen's book he says:

Natural language processing (NLP) underwent a profound transformation in the mid-1980s when it changed to make heavy use of corpora and data-driven techniques for language analysis. Since then, the use of statistical techniques in NLP has evolved in various ways. An example of evolution took place in the late 1990s or early 2000s, when full-blown Bayesian approach to NLP has come to make up for by solving several deficiencies in the frequentist approach and enriching it, especially in the unsupervised environment, where statistical learning is carried out without examples of goal prediction.

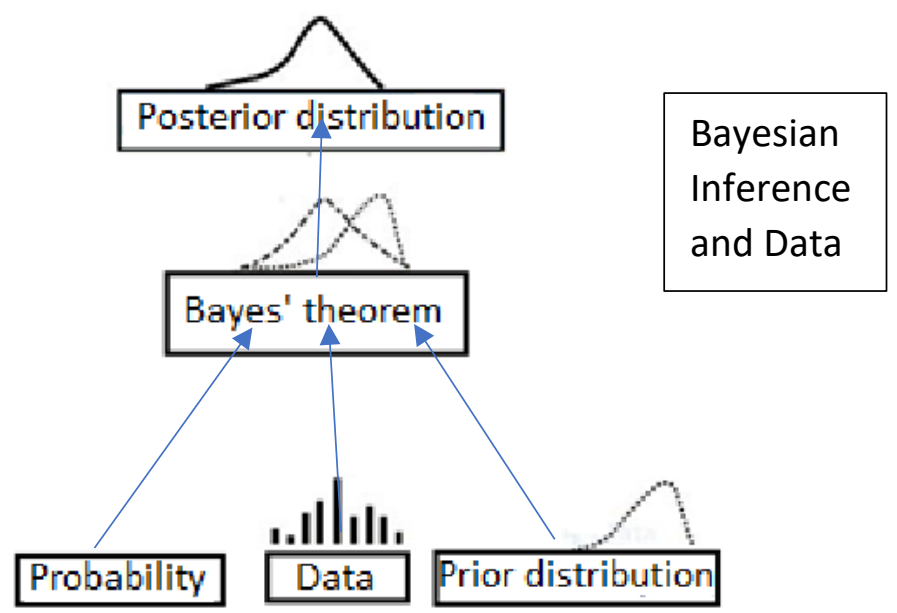

Fig. 2

In summary: We have seen this use of Bayesian probability (Fig. 2), in epidemiology models, to determine models of evolution of data on contagion and deaths in COVID and in natural language processing. But we could also see it in a multitude of cases in the most varied scientific ad process analysis field. In this way, with the automation of Bayesian methods and the use of probabilistic graphical models, it is possible to identify patterns and anomalies in voluminous data sets in fields as diverse as linguistic corpus, astronomical maps, add functionalities to the practice of the magnetic resonance imaging, or to card, online or smartphone purchasing habits. This is to indicate 
only a few cases, such as those associated with big data analysis and Bayesian theory. But there are many more (Bundy, 2007; Wing, 2008 cited in Zapata-Ros, 2020 August).

Thus, this scheme that we have analyzed in The Lancet article is present in many cases. Thus, we said (Zapata Ros, August 2020) that, if we consider that Bayesian thinking, this way of proceeding, as one more and more relevant element of computational thinking, then to what has been said on previous occasions we must now add the idea of pervasive computational thinking as an advance and development of what is dealt with in simple computational thinking, which Wing (2006) raises in his first approach.

In this way, we speak of "computational thinking everywhere" (Wing, 2008). It is done when considering that it is no longer purely associated with life and the world of work, as what we have called computational thinking until now, but as a preparation for the basic research and for research methodology in almost all disciplines. In this way, we speak of "computational thinking everywhere" (Wing, 2008). It is done when considering that it is no longer purely associated with life and the world of work, as what we have called computational thinking until now, but as a preparation for the basic research and for research methodology in almost all disciplines. Thus defined, computational thinking is influencing research in the humanities (Bundy, 2007). Evidence abounds on the influence of computational thinking in other fields: It is transforming statistics, where with machine learning, automation of Bayesian methods and the use of probabilistic graphical models it is possible to identify patterns and anomalies in voluminous data sets.

To what has been said above, it must be added that the perspective of a "Bayesian thinking" comes from much further back and only partially overlaps with data analytics. In fact, this can be considered as one element of a very broad methodology cited by Wing (2008) applied to a very broad series of cases and processes.

In both cases the scheme is the same. Bayes' Theorem, in a version for a large number of variables, takes as partial inverse probabilities those provided by the data analysis processes. For example, deaths in cases of the pandemic in the countries that first suffered it, obtaining what was the probability function of cases conditioned to that of deaths, assuming that these could be biases or falsified. This allowed some countries to stock up. Other do not. This same mechanism appears in the complex and diverse cases that Bundy (2007) points out as a particular case in what he calls pervasive computational thinking.

As an element of computational thinking, Bayes thinking is very simple, understandable, and obtainable as learning and its use as a skill from high school. The simplest expression of Bayes' Theorem is the inverse probability theorem and formula. It has all the elements of Bayes' Theorem and its use includes all the elements and characteristics of this way of thinking.

Its deduction is very simple, but it is not a question of treating it here (Fig. 3), and the formula is

The bayesian thinking, a pervasive computational thinking.. 


$$
P(A / B)=\frac{\mathrm{P}(\mathrm{B} / \mathrm{A}) \cdot \mathrm{P}(\mathrm{A})}{P(B)}
$$

Fig. 3

It is necessary to previously know the concept of conditional probability. That is a probability that is assigned to an event $\mathrm{A}$, conditional on the occurrence of another event $\mathrm{B}$, and it is written $\mathrm{P}(\mathrm{A} / \mathrm{B})$.

In this way the formula allows us to obtain the probability of A conditional on $\mathrm{B}$ --- P (A/B) --- in function or knowing the probability of B conditional on A --- P (B/A) -- or inverse probability.

A very frequent use, and one that gives an idea of its potency, is that of obtaining the efficiency of a test, such as the PCR for COVID 19.

Thus, for example, it allows us to obtain the probability that someone is sick with COVID when the PCR tests positive, depending on the probability of the inverse event: The probability that the PCR test tests positive while the individual is ill. As can be seen, the probability in the second case is very easy to obtain by passing the PCR test to a population that we know positively is sick because it has been diagnosed. However, the first is completely unknown to us.

In the same way, we can know a priori the probability that someone is sick $\mathrm{P}(\mathrm{A})$, from the empirical data and the frequency with which the disease appears. We can also calculate the probability that the test is positive, from the empirical data on the cases, when in a population without other previous data, chosen at random, for example, the test is positive.

Bayes' Theorem in its classical and complete version is formulated for the case in which the event A can be decomposed into a complete and exclusive set of elementary cases. This allows us to obtain the probability of A, or of any of the events into which it is decomposed, by the compound probability formula through a set of a few elementary events. When the population is very large and there are many elementary events, it is when data analytics is used to compute these large masses of data, process them and obtain the frequencies.

Bayes formula then is:

$$
P\left[A_{n} / B\right]=\frac{P\left[B / A_{n}\right] \cdot P\left[A_{n}\right]}{\sum P\left[B / A_{i}\right] \cdot P\left[A_{i}\right]}
$$

Fig. 3

Let's think that event A is having COVID, and that the decomposition into a set of complete and exclusive cases can be determined by age ranges, areas of origin, 
pathological profiles, etc. In this case we would be on the assumption offered by The Lancet magazine, whose results are extremely powerful with a very simple mathematical apparatus.

Another notable issue is that an instruction focused on this component of computational thinking, or including it, at an early stage, in Secondary with the inverse probability formula, would enable these learnings to be activated as highly valuable and complex components at a later stage of learning, the professional or research activity, or in the training phase, undergraduate and postgraduate degrees, of these professions or that train for these activities and professions.

\section{The idea and definition of computational thinking so far}

In what follows we will talk about the relevance of research ecosystems on computational thinking and its dissemination. We will also talk about the research and dissemination for a conception of computational thinking. Specifically, we will do so taking into account a specific scheme and a singular definition, the holistic one by components, of computational thinking and how Bayesian thinking is integrated into that scheme.

In 2016, the UE report Developing computational thinking in compulsory education, European Commission, in JRC Science for Policy Report 68 (Bocconi et al, 2016) echoes the work (Zapata-Ros, 2015) entitled "Computational thinking: A new digital literacy", in particular of the holistic definition by components.

A rigorous work on the subject is the one published by Roig-Vila and MorenoIsac (2020) Computational Thinking in Education. Bibliometric and thematic analysis. It tries to analyze the scientific literature on the application of computational thinking in Education, taking as a reference the main collections of the Web of Science database. For this, a systematic review is carried out in which the variables year of publication, countries with more productions, more productive authors in this field and the documentary sources with the largest number of publications have been taken into account, which is what in our opinion. Interesting purpose, but also the authors "have made a classification according to the types of documents and research methods used, as well as the educational stages under study and the programming languages used".

To understand Bayesian thinking as a component of computational thinking, it is first necessary to know its conceptualization, what makes it possible and where it is inserted.

In the following lines we are going to develop, starting from a general concept and in the simplest possible way, this conceptualization of computational thinking as a set of elements that have in common not only their character as basic skills in a new inculturation, but also their character of skill sets that come together and combine 
harmoniously to solve vital and professional problems. That is, it is knowledge oriented to practice and cultural development.

In its simplest sense, computational thinking is seen as a set of specific skills that are used by programmers to do their homework, but are also useful to people in their professional and personal lives as a way to organize their work, solving their problems, and representing the reality around them. In a more elaborate scheme, this complex of skills constitutes a new literacy --- or the most substantial part of it --- and an inculturation to deal with a new culture, the digital culture in the knowledge society.

In its beginnings, back in 2012 (Stross, March 31, 2012), great importance was given to this set of skills as the basis of a training that was necessary in the world of production, commerce and services, where computers and the networks constituted the support and the path through which the flows of all activities circulated, but not only in production and commerce, but also in their management and control.

In November-December 2014 (Zapata-Ros, 2014) we pointed out that society, the economy, demands qualified professionals in the information industries. This has sensitized politicians and institutions to approach the problem from the point of view of training. The most advanced societies have seen that as such it is necessary to start from the earliest stages of individual development, as is the case with other key skills: reading, writing and skills math. The dilemma was raised between teaching programming included in the basic contents of the curriculum or accepting that there is one's own thinking, just as there is a heuristic or divergent thinking - which is already called computational thinking, and which some of us have called precoding (algorithmic, topdown analysis, bottom-up analysis, modularization, recurrence, backtracking,...) - and that we should start with a design that favors the acquisition of this thought from the first stages of learning. In our proposal we opted for the second an established the definition of computational thinking by component (quote) in the book "Computational thinking, analysis of a key competence".

Before, what we consider to be classical definitions were formulated, those that are repeated in articles and conferences, those that synthetically, as we will see, and therefore partial the most striking aspects of computational thinking, and that, as in the case of Win (2008), soon they were replaced by more complex definitions and therefore more adjusted to the complexity of the phenomenon.

The first of which we have news with this name and clearly referring to this concept is that of the computer science Tasneem Raja (2014) in the post ; We Can Code It !, from the magazine-blog Mother Jones that uses the image of reality as a puzzle. It is an intuitive way in which an author, who comes from the computational world, deals with a series of methods widely known in the world of learning psychology, in addition to computing. Implicitly he is talking about top-down and elaboration analysis. 
But the best- known definition is that of Wing (2006), which is always used. It is very general and easily understandable and acceptable by the reader, bur is does not give us concrete guidelines to discern what is computational thinking from other skills that are not, and above all to make those skills operational or give concrete references:

Computational thinking consists of problem solving, system design, and understanding of human behavior design, and understanding of human behavior making use of the fundamental concepts of computer science.

Everything would really fit there. In fact, today it is already something obvious and inevitable in any discipline or learning of a professional or scientific practice. But it lacks a holistic sense that gives it its own meaning as an inculturation or literacy of its own.

Subsequently, other definitions are produced, such as that of Grove (2018, March 13), which constitutes part of the objective of this work, which we have seen in detail in the previous section, and other subsequent definitions of Wing itself (2008), one of which we have taken precisely to introduce the concept of Bayesian thought. avoided.

Finally, in a quick summary, the definition by components (holistic) cannot be

We have been developing this conceptualization and the corresponding definition since June 2014 (Zapata-Ros, 2014) and, to this day, its clearest and most definitive expression in the book Computational thinking, analysis of a key competence (PérezParedes and Zapata-Ros, 2018), in addition to academic posts (Zapata-Ros, December 2018) (Zapata-Ros, 2014), in the article Computational thinking: A new digital literacy (Zapata-Ros, 2015) and in numerous preprints.

On March 13, 2018 the article is published: The 5h ' $C$ ' of 21st Century Skills? Try Computational Thinking (Not Coding), by Professor Shuchi Grover (2018, March 13), from Stanford, in which I saw for the first time, and in the absence of another reference, the author finds someone different and distant, without prior contact from any kind, how could it be otherwise, consider computational thinking as an accumulation of skills and elements of knowledge necessary to program and to progress in your professional and personal life, in the digital society.

In the section dedicated to defining and delimiting Computational Thinking (PC), the author says that it is made up of [1]

“(...) The thought processes involved in understanding a problem and expressing its solutions in such a way that a computer can potentially carry out the solution. CT is fundamentally based on the use of analytical and algorithmic concepts and strategies more closely related to computer science to formulate, analyze and solve problems.

Like general thinking skills, CT is a bit like the [concept of] leadership: it's hard to define, but you know it when you see it. While many people associate

The bayesian thinking, a pervasive computational thinking.. 
it with concepts like programming and automation, which are all central parts of computing, educators and researchers have found it easier to operationalize for the purposes of teaching, curriculum, and assessment design.

That means breaking down CT skills into its component parts, which include concepts like logic, algorithms, patterns, abstraction, generalization, evaluation, and automation. It also means approaches such as "decomposing" problems into subproblems to facilitate resolution, creating computational artifacts (usually through coding); reusing solutions, testing and debugging; iterative refinement.

¡And yes, it also involves collaboration and creativity! And, furthermore, it doesn't need to involve a computer.

Let's see then, from the outset it points out the difficulty of defining PC. So, you take the position of defining what $\mathrm{P}$ is as, or by a set of things (that means breaking down computational thinking skills into their component parts), most of them involve or are skills, but they are always easy to operationalize. (They are all central parts of informatics, educators and researchers have found easier to operationalize it (Shields \& Rangarajan, 2013) for the purposes of teaching, curriculum and assessment design) and above all they are possible to include in an educational design.

They are skills that include powers to operationalize logic (logical thinking), algorithms (algorithms), patterns, abstraction (abstract thinking), generalization (bottomup thinking), evaluation and automation. It also means approaches such as "decomposing" problems into subproblems to facilitate resolution (top-down thinking), creating computational artifacts (usually through coding); reusing solutions, testing and debugging (trial and error); iterative refinement (iteration).

¡To conclude by saying that "it also implies collaboration (collaborative methods) and creativity"!

This definition coincides at least in ten of the fifteen elements of the holistic definition by components that we have indicated (Zapata-Ros, 2015).

It also coincides, in the vision of a new key skill, in the context of the dynamics of literacies and of what digital literacy is. In his article, Groves points out the relevance of Computational Thinking in that it constitutes one more competency to add to those already accepted as competencies for the digital society. In any case, what both developments, Graves' article and the undersigned, have in common is that computational thinking represents a turning point.

In the case of Shuchi Groves (2018, March 13), from the title (The 5th ' $C$ ' of 21st Century Skills? Try Computational Thinking (Not Coding)? [2], it is pointed out that computational thinking adds a fifth $\mathrm{C}$ to the already four "ces" of digital competences indicated and accepted by all. 
How the new Thought component, which we have defined as Bayesian, is inserted in the framework of Computational Thinking

Today there is an intellectual revolution of incalculable scope. It is happening all around us. However, in the opinion of authors like Bundy (2007) few are perceiving it and even fewer are those who have commented on it in articles or other academic writings, papers, essays, etc. Something like computational thinking, which was originally studied in relation to learning and education, is now influencing research, in almost all disciplines, both in the sciences and in the humanities.

At the beginning, we pointed out some cases to determine models of data evolution on contagion and deaths in COVID and natural language processing. Now, we are going to pick up some interesting ideas that were originally raised in a meeting and in a series of seminars and workshops in Edinburgh. In them, participants pointed to research and researchers who are using computational metaphors to cognitively organize "theories as diverse as proto-economics and the mind-body problem" (Bundy, 2007). To the initial appreciation that computer science has allowed researchers to formulate new types of questions, based on what affordances do, and to integrate new types of answers into studies and reports, such as, for example, questions that require processing of large amount of data, you can add a new appreciation that underlies in all cases: What is it that relates the a priori perception of the phenomena studied with the establishment of principles or general or future results. In all cases this Bayesian principle is observed: Combine data analytics, to establish a priori probabilities, with the Bayes formula.

In this way, we see that the capacity of computational thinking, to help formulate new and innovative orientations to research, is not limited to the closed field of electronic computer science. There is something beyond that, which integrates other fields and particularly Bayesian thought. Over the course of the seminar (Bundy, 2012) he suggested by way for example something that could illustrate the point. This is a facial recognition problem, initially raised by Vicki Bruce and her collaborators (Bundy, 2012). It could not be solved only by using image transformation techniques. For this he used the case (Bundy, 2007) of a well-known sequence of images that transform Tony Blair into Margaret Thatcher in five stages.

In this context, he pointed out that Bruce's first experiments with photos, cut and paste, were not enough. It was too crude to provide the fine gradations, the sequence between the necessary images that were available, to establish a continuity between hypotheses psychologically acceptable to the observer. Bruce's work (2005 cited in Bundy, 2007) also showed that you cannot just adapt early work feature-based approaches to computer vision and expect this to provide a psychologically valid, ready-to-use description of human vision. Instead, and this is what is important, faces can be encoded in memory by abstracting them into a small collection of archetypal features. So, facial recognition consists of matching the current image with the most similar archetype, but according to a similarity criterion based on a Bayesian model of the type of "what is the

The bayesian thinking, a pervasive computational thinking.. 
probability that this feature is compatible or evolution of one that we have when the frequency in reality of the cases that we have is known". And set a critical probability as acceptable. It would be a kind of variation of the PageRank or Science Citation Index (SCI) algorithm but with the inverse probability formula and the Bayes formula.

This is one of many cases that can be raised, some of which were discussed at the University of Edinburgh seminar (Bundy, 2012). They can give an idea of the variety of occasions in which not only computational thinking but variants of the Bayes formula and Big Data can be applied in all kinds of disciplines and to all kinds of investigative thinking. Despite this breadth of situations, who is in charge in each case, the key issues come from and continue to emerge from each discipline. These factors, such as the ability that computational thinking provides to investigate new lines or to pose new questions that previously was not possible from the classical perspective; the infiltration of computational concepts in the theories of other disciplines; and above all the relationship between these factors and their influence on the result through Big Data with Bayes, make the analysis subtler and deeper, through the keys provided by the disciplines themselves.

Until now the discourse was that computational thinking would influence everyone in all fields of activity. As a consequence, this vision poses a new educational challenge for our society, especially for our children. When thinking about computing, we must be in tune with the three drivers of our field: science, technology and society. Accelerating technological advances and the monumental demands of society force us to review the most basic scientific questions of computing. But this vision stayed there, in adopting an approach to solve problems, design systems and understand human behavior that is based on fundamental concepts for computing (Wing, 2006). Vision that everything else was completed and broken down with the contributions of Suchi Grover (2018, March 13) and who writes (Zapata-Ros, 2015).

Another characteristic that it had and that now changes, is that computational thinking is a derivation of previous thoughts, coexisting with other disciplines separately, although our contribution was holistic (Coll, 2019). Thus, in general it was constituted by a kind of analytical thinking from mathematics, logic, engineering, etc. Until now, in a subsidiary way with respect to these matters, it shared with mathematical thought the general ways in which we could approach the resolution of a problem. In particular, he shared with engineering thinking the general procedures with which we could study the design and evaluation of a large and complex system, operating with the limitations of the real world. With scientific thinking, it shared general aspects with which we can analyze the understanding and mastery of computability (mathematics, logic, electronics). And, he shared with psychology, the way problems, intelligence, cognition and human behavior are studied.

But now, not only an educational issue has changed, but a procedural and methodological issue that permeates and infiltrates all scientific and professional activity, especially from Bayesian thought, and that acquires a relevance and an entity of its own, independent of the disciplines of which, before it was subsidiary, sharing its fragmentary character.

The bayesian thinking, a pervasive computational thinking.. 
This leads us say that it is a pervasive computational thinking (pervasive computational thinking), largely determined by its Bayesian component. It is a thought that has its own entity.

Both Wing (2008) and Bundy insist on this idea: "Computational thinking is influencing research in almost all disciplines, both in the sciences and in the humanities" (Bundy, 2007). But it is that author who explicitly affirms the power of the Bayesian model: "Evidence abounds of the influence of computational thinking in other fields: computational thinking in particular is transforming statistics. Where, with automatic learning brought about by the automation of Bayesian methods and the use of probabilistic graphical models, they allow the identification of patterns and anomalies in large data sets". This procedure is equally present in fields as diverse as in the elaboration of astronomical maps, in the elaboration of images and representations of magnetic resonance scans, recognition of patterns of purchases with credit cards and their receipts issued by sales areas, etc.

In addition to what has been said, Fisher and Henzinger (2007) point out this form of computational thinking as something capable of "transform biology". They use two cases, the first is the "shotgun sequencing algorithm"1 that accelerates our ability to

\footnotetext{
${ }^{1} \mathrm{Si}$ escribimos en Google "shotgun sequencing algorithm, bayesian methods" aparece una gran cantidad de trabajos:

\begin{tabular}{|c|c|c|c|c|c|c|}
\hline Goo: & & tgun seque & cing algorith & , bayesian $\mathrm{m}$ & thods & \& \\
\hline Q Todo & 园 Imágenes & $\bigoplus$ Vídeos & 国 Noticias & $\odot$ Shopping & : Más & Herramientas \\
\hline
\end{tabular}
}

\footnotetext{
Artículos académicos para shotgun sequencing algorithm, bayesian methods

... in environmental whole-genome shotgun sequencing - Chan - Citado por 85

Genome skimming by shotgun sequencing helps ... - Malé - Citado por 98

Metagenomic shotgun sequencing of a Bunyavirus in ... - Chandler - Citado por 43
}

https://repositories.lib.utexas.edu > ... $\vee$ Traducir esta página

Bayesian inference methods for next generation DNA ...

de X Shen - 2014 - Citado por 2 - However, accuracy and lengths of the short reads are yet to surpass those provided by the conventional slower and costlier Sanger sequencing method.

https://pubmed.ncbi.nlm.nih.gov > ... · Traducir esta página

A Bayesian approach to DNA sequence segmentation - PubMed $\bullet$

de RJ Boys · 2004 · Citado por 118 — This article describes a Bayesian method that identifies such segments by using a Markov chain governed by a hidden Markov model. Markov chain...

https://pubmed.ncbi.nlm.nih.gov > ... · Traducir esta página

The bayesian thinking, a pervasive computational thinking.. 
sequence the human genome. The second is the use of abstract thinking, similar to or included in computational thinking, to represent dynamic processes found in nature, from the cell cycle to protein folding. Finally, Abraham, Blum and Sandholm (2007) present cases in economics, noting that "computational thinking is transforming the economy, generating a new field of computational microeconomics, with applications such as ad placement, online auctions, reputation and even find optimal donors renal exchange".

In this way, one speaks indistinctly of a pervasive computational thinking, an omnipresent computational thinking that permeates everything, which is pervasive. Definitely, computational thinking everywhere.

\section{Conclusions for practice}

From all that has been said, what conclusions can we draw for practice, in the training of our students, about what we have conceptualized as Bayesian computational thinking, or what Bundy (2007) and Wing (2008) have called pervasive computational thinking, so that these learnings, concepts and skills can be activated in their university or professional training?

And, above all, what curricular design and what instructional design we will do in Primary, Secondary (K-12) and Baccalaureate (High School) for this to be possible. Finally, what does the literature review currently tell us?

After a first investigation, sticking to what they offer us, with respect to practice and research on these issues, science dissemination platforms and scientific repositories (Core Collection of WoS, CiteScore, SJR of SCImago and Google Scholar), we come to the conclusion that there are two ways to go.

One is the one presented by the work of Joshua M. Rosenberg (2020), where the question is to treat the problem directly by the students and skills for it. According to this approach, the aim is for students to develop skills to establish models and patterns in science, of a scientific nature, from large masses of data and, obviously, from Bayes' Theorem. But without penetrating the nature of it, but simply with the application of tools that integrate them (data analysis from preliminary results and Bayes formula) for the establishment of relationships and connections between previous hypotheses and certain scientific laws, which are they previously postulate in a hypothetical way, and are formulated according to the logic and syntax (the style) of science.

This is for students to learn the logic, dynamics, and nature of science. Also, of his method and his language.

Therefore, what would develop, according to this trend, is not a computational thought, as we have always considered it, but a scientific thought. Or rather a method that is now seen as very frequent, powerful and necessary: 
The combination of the Bayes Formula with big data analysis. Learning a new scientific methodology.

The other option is for students to learn what Bayes' Theorem is and apply its deep nature --- what it is made for and defined for --- in order to apply it to solving concrete problems in the real world of science, the arts or the profession, in the same way as was done with other elements of Computational Thinking (Zapata-Ros, 2015) (Grover, 2018). Of these, let us recall top-down analysis, bottom-up analysis, recursion, metacognition, divergent thinking, etc.

Let us remember that then (Zapata-Ros, 2015) we understood learning as something complex, deep. With dominance (mastery learning) (Zapata-Ros, Feb. 2021, p. 40) (Bloom, May. 1976, p. 68), understanding by such (Zapata-Ros, 2021, p. 34) (Gagné, 1965, 1985) (Gagné \& Briggs, 1974) (Merrill, 2002a, 20002b, 2009 and 2012) that there is understanding, attribution of meaning and incorporation to the baggage of ideas, methods, procedures and values of the student, that the student can work with these learnings autonomously and, finally, that they can transfer it to new and original situations, analyzing and acquiring in addition, the ability to recognize what are the problems that are solved with these methods. But, above all, it is learning in the sense that it admits an evaluation based on the recognition of that domain, on the achievement of each student.

Well, currently we have not found any case in which, this is raised like this in K12 (Secondary), or in the equivalent educational level of other countries, in a similar way to how it is done with Computational Thinking, with the same features, somewhere. This does not diminish its importance, but reveals that it is a very early approach.

Of course, the foundation of this educational practice would be similar to what we have seen for unplugged: The activation principle (Merrill, 2002a, 20002b, 2009 and 2012). But this situation only confirms that we are at a very early stage of the matter.

Presentación del artículo: 1 de julio 2021

Fecha de aprobación:

Fecha de publicación: 30 de noviembre de 2021

Zapata-Ros, M. (2021). The bayesian thinking, a pervasive computational thinking. RED. Revista de Educación a Distancia. Núm. 68,

DOI:http://dx.doi.org/10.6018/red.496321

\section{Financing}


This work has not received any specific grant from funding agencies in the public, commercial, or non-profit sectors.

\section{Bibliographic references}

Abraham, D., Blum, A. \& Sandholm, T. 2007 Clearing algorithms for barter exchange markets: enabling nationwide kidney exchanges. In Proc. 8th ACM Conf. on Electronic Commerce, pp. 295-304. New York, NY: Association for Computing Machinery.

Barrow, B. (2019 Apr) Bayesian Analysis in Natural Language Processing: Cohen. https://linguistlist.org/issues/30/30-1843/

Bloom, B. S. (1984a). The 2 sigma problem: The search for methods of group instruction as effective as one-to-one tutoring. Educational researcher, 13(6), 4-16. https://www.jstor.org/stable/pdf/1175554.pdf

Bloom, B. (May 68). Learning for Mastery. Instruction and Curriculum. https://files.eric.ed.gov/fulltext/ED053419.pdf

Bloom, B. S. (1976). Human characteristics and school learning. McGraw-Hill, p. 59 de 63

Bloom, B. (1984b). The 2 Sigma Problem: The Search for Methods of Group Instruction as effective as One-to-One Tutoring, Educational Researcher, 13:6 (4-16). https://inst.eecs.berkeley.edu// cs375/sp15/resources/Bloom_The2SigmaProblem.pdf

Bocconi, S., Chioccariello, A., Dettori, G., Ferrari, A., Engelhardt, K., Kampylis, P. \& Punie, Y. (2016). Developing computational thinking in compulsory education. European Commission, JRC Science for Policy Report, 68.

Bruce, V. (2005). About Face. http://www.inf.ed.ac.uk/research/programmes/compthink/slides/Bruce.pdf

Bundy, A. 2007 Computational thinking is pervasive. J. Scient. Pract. Comput.1, 6769. https://www.inf.ed.ac.uk/publications/online/1245.pdf

Bundy, A. (2012) COMPUTATIONAL THINKING SEMINARS. SCHOOL OF INFORMATICS. University of Edinburgh. https://www-inf-ed-acuk.translate.goog/research/programmes/comp-

think/previous.html?_x_tr_sch=http\&_x_tr_sl=en\&_x_tr_tl=es\&_x_tr_hl=es\&_x_tr_pt $\mathrm{o}=$ nui,op

Cohen, S. (2019). Bayesian analysis in natural language processing. Synthesis Lectures on Human Language Technologies, 12(1), 1-343.

Coll, C. (2019). Presentación y prólogo del libro" El pensamiento computacional. Análisis de una competencia clave". Revista de Educación a Distancia, 19. https://revistas.um.es/red/article/view/395281 
Drury, B. (2019 Aug). Bayesian Analysis in Natural Language Processing, in Review: Computational Linguistics; Text/Corpus Linguistics: Cohen (2019). https://linguistlist.org/issues/30/30-4380/

Fisher, J. \& Henzinger, T. A. 2007 Executable cell biology. Nat. Biotechnol. 25, 1239-1249. (doi:10.1038/nbt1356)

Gagné, R. M. (1965). The conditions of learning and theory of instruction (1st ed.). New York, NY: Holt, Rinehart \& Winston.

Gagné, R. M., \& Briggs, L. J. (1974). The principles of instructional design (1st ed.). New York, NY: Holt.

Gagné, R. M. (1985). The conditions of learning and theory of instruction (4th ed.). New York, NY: Holt, Rinehart \& Winston. Gagne, R. M. \& Medsker, K. L. (1996). The conditions of learning: Training applications. Fort Worth, TX: Harcourt Brace College Publishers.

Grover, S. (2018, March 13). The 5th 'C' of 21st century skills? Try computational thinking (not coding. Retrieved from EdSurge News: https://edtechbooks.org/-Pz

Merrill, M. D. (2002a). First principles of instruction. Educational technology research and development, $50(3)$,

43-59. http://csapoer.pbworks.com/f/First+Principles+of+Instruction+(Merrill,+2002).pdf

Merrill, M. D. (2012). First principles of instruction. John Wiley \& Sons. Merrill, M. D. (1991). Constructivism and instructional design. Educational technology, 31(5), 45-53.

Merrill, M. D. (2002b). First principles of instruction. Educational Technology Research and Development, 50(3), 43-59. Instructional-Design Theories and Models, Volume III: Building a Common Knowledge Base.

Merrill, M. D. (2009). First Principles of Instruction. In C. M. Reigeluth \& A. Carr (Eds.), Instructional Design Theories and Models: Building a Common Knowledge Base (Vol. III). New York: Routledge Publishers.

Raja, T. (2014). We Can Code It! Why computer literacy is key to winning the 21st century. Mother Jones, June.

Shields, P. M., \& Rangarajan, N. (2013). A playbook for research methods: Integrating conceptual frameworks and project management. New Forums Press.

Roig-Vila, R., \& Moreno-Isac, V. (2020). El pensamiento computacional en Educación. Análisis bibliométrico y temático. Revista de Educación a Distancia, 20(63). https://revistas.um.es/red/article/view/402621

Rosenberg, J. (2020). More confidently uncertain? Teaching learners to apply Bayesian methods to make sense of scientific phenomena. https://joshuamrosenberg.com/publications/rosenberg-2020-icls-ecw-copyright.pdf $\quad y$ https://edarxiv.org/7rptw/download

Stross, R. (31 de marzo de 2012) Computer Science for the Rest of Us. https://www.nytimes.com/2012/04/01/business/computer-science-for-non-majors-takesmany-forms.html 
Verity, R., Okell, L. C., Dorigatti, I., Winskill, P., Whittaker, C., Imai, N., ... \& Ferguson, N. M. (2020). Estimates of the severity of coronavirus disease 2019: a model-based analysis. The Lancet infectious diseases, 20(6), 669-677. https://www.thelancet.com/journals/laninf/article/PIIS1473-3099(20)30243-7/fulltext y https://www.thelancet.com/action/showPdf?pii=S1473-3099\%2820\%2930243-7

Wing, J.M. (2006) Computational thinking. it represents a universally applicable attitude and skill set everyone, not just computer scientists, would be eager to learn and use. Commun. ACM 49(3). https://doi.org/10.1109/vlhcc.2011.6070404

Wing, J.M. (July 2008) Computational thinking and thinking about computing. The Royal Society Publishing. https://doi.org/10.1098/rsta.2008.0118 https://royalsocietypublishing.org/doi/10.1098/rsta.2008.0118 https://royalsocietypublis hing.org/doi/pdf/10.1098/rsta.2008.0118

Zapata-Ros, M. (2014) https://red.hypotheses.org/776

Zapata-Ros, M. (2015). Pensamiento computacional: Una nueva alfabetización digital. RED. Revista de Educación a Distancia, (46). Recuperado de: https://www.um.es/ead/red/46/

Zapata Ros, M. \& Pérez Paredes, P. (2018). El pensamiento computacional, análisis de una competencia clave. New York: Create Space Independent Publishing. https://www.amazon.es/pensamiento-computacional-analisis-competenciaclave/dp/1718987730

Zapata-Ros, M. (Enero, 2018) https://red.hypotheses.org/1079

Zapata-Ros, M. (January 2019) Pensamiento computacional desconectado. http://dx.doi.org/10.13140/RG.2.2.12945.48481

Zapata-Ros, M. (Agosto, 2020). El pensamiento computacional, una cuarta competencia clave planteada por la nueva alfabetización (II). Una nueva línea: computational thinking everywhere, pervasive computational thinking y el pensamiento bayesiano. RED de Hypotheses. https://red.hypotheses.org/2123

Zapata-Ros, M. (Febrero, 2021). Capítulo 5. La evaluación en la educación de la pandemia y después de la pandemia. DOI: 10.13140/RG.2.2.21911.29605 http://dx.doi.org/10.13140/RG.2.2.21911.29605 , y https://www.researchgate.net/publication/349212529_Capitulo_5_La_evaluacion_en_la _educacion_de_la_pandemia_y_despues_de_la_pandemia?channel=doi\&linkId=60250c 0e92851c4ed563a7be\&showFulltext=true 
[1] It is the thought processes involved in understanding a problem and expressing its solutions in such a way that a computer can potentially carry out the solution. CT is fundamentally about using analytic and algorithmic concepts and strategies most closely related to computer science to formulate, analyze and solve problems.

Like general thinking skills, CT is a bit like leadership — hard to define, but you know it when you see it. While many people associate it with concepts like programming and automation - which are all core parts of computer science-educators and researchers have found it easier to operationalize it for the purposes of teaching as well as curriculum and assessment design.

That means breaking down CT skills into its component parts, which include concepts like logic, algorithms, patterns, abstraction, generalization, evaluation, and automation. It also means approaches like "decomposing" problems into subproblems for ease in solving, creating computational artifacts (usually through coding); reusing solutions, testing and debugging; iterative refinement.

And yes, it also involves collaboration and creativity! And furthermore, it does not need to involve a computer.

\section{[2] ¿La 5ta 'C' de las habilidades del siglo XXI? ¿Es de verdad el pensamiento} computacional? 